\title{
ANALISIS FINANCIAL DISTRESS : OPERATING CAPACITY, LEVERAGE, DAN PROFITABILITAS
}

\author{
Wiwi Idawati \\ Sekolah Tinggi Ilmu Ekonomi Indonesia Banking School \\ Email :wiwi.idawati@ibs.ac.id
}

\begin{abstract}
The purpose of this study is to anticipate the occurrence of corporate financial difficulties, and to determine the effect of operating capacity, leverage, and profitability on financial distress in goods and consumption industry companies The population in this study used goods and consumption industry companies listed on the Indonesia Stock Exchange in 2015-2018, using purposive sampling data collection techniques, the sample in this study were 44 companies with a period of 4 years. The results of this study prove that simultaneously operating capacity, leverage and profitability significantly influence financial distress. While partially operating capacity and leverage does not affect financial distress, while profitability proxied with return on equity has an influence on financial distress.
\end{abstract}

Keywords; Financial Distress, Operating Capacity, Leverage, Profitability, Return on Equity

Abstrak: Tujuan daripada penelitian ini untuk mengantisipasi terjadinya kesulitan keuangan perusahaan, dan untuk mengetahui pengaruh operating capacity, leverage, dan profitabilitas terhadap financial distress pada perusahaan industri barang dan konsumsi. Populasi yang dalam penelitian ini menggunakan perusahaan industri barang dan konsumsi yang terdaftar di Bursa Efek Indonesia tahun 2015-2018, dengan menggunakan teknik pengumpulan data purposive sampling, sampel pada penelitian ini sebanyak 44 perusahaan dengan periode 4 tahun. Hasil penelitian ini membuktikan bahwa secara simultan operatimg capacity, leverage dan profitabilitas berpengaruh terhadap financial distress. Sedangkan secara parsial operating capacity dan leverage tidak berpengaruh terhadap financial distress, sedankan profitabilitas yang diproksi kan dengan return on equity memiliki pengaruh terhadap financial distress.

Kata kunci: Financial Distress, Operating Capacity, Leverage, Profitabilitas, Return on Equity

\section{Pendahuluan}

Kondisi ekonomi yang selalu mengalami perubahan telah mempengaruhi kegiatan dan kinerja suatu perusahaan, baik itu perusahan besar maupun perusahaan kecil sehingga banyak perusahaan yang bangkrut terutama perusahaan yang terdaftar pada Bursa Efek Indonesia. Ditambah lagi dengan muncul MEA (Masyarakat Ekonomi ASEAN) menyebabkan ancaman kepada industri-industri yang tidak siap menghadapi persaingan dengan baik sehingga perusahaan akan mengalami kesulitan keuangan yang akan menimbulkan kebangkrutan (Al-Khatib, 2012). Kesulitan ekonomi suatu perusahaan yang tengah berada dalam kondisi financial distress atau kesulitan keuangan ini menyebabkan beberapa perusahaan publik di Bursa Efek Indonesia (IDX) mengalami delisting karena tidak mampu mempertahankan keberlangsungan hidup perusahaan (Masdupi, 2018).

Seiring dengan krisis multi dimensi yang melanda Indonesia, banyak masalah dan penderitaan yang dialami bangsa ini. Yang termasuk menonjol adalah dalam aspek ekonomi, yakni terpuruknya kegiatan ekonomi karena semakin banyak perusahaan yang bangkrut, perbankan yang dilikuidasi dan meningkatnya jumlah tenaga kerja yang menganggur. Penyebab dari krisis ini, menurut Gholizadeh (2011), bukanlah karena fundamental ekonomi yang lemah saja, tetapi karena utang swasta luar negeri yang telah mencapai jumlah yang 
cukup besar. Krisis yang berkepanjangan ini adalah krisis merosotnya nilai tukar rupiah yang sangat tajam, akibat adanya spekulasi dan jatuh temponya utang swasta luar negeri dalam jumlah yang besar dan secara bersamaan sehingga permintaan akan dollar meningkat, ditambah lagi dengan banyak terjadinya bencana alam yang mengakibatkan nilai tukar rupiah yang semakin lemah (Pustylnick, 2012).

Kondisi keuangan sebuah perusahaan merupakan informasi yang sangat berharga bagi pihak-pihak baik diluar maupun didalam perusahaan. Apabila kondisi keuangan perusahaan dalam keadaan baik, maka kelangsungan hidup perusahaan dapat terus terjaga sehingga secara umum memberikan pengaruh yang positif terhadap semua pihak (Nella, R.2011) Namun setiap perusahaan tentu memiliki kemungkinan untuk mengalami keadaan dimana kondisi keuangan tidak stabil bahkan berujung pada kebangkrutan perusahaan. Financial distress atau kesulitan keuangan adalah tahapan penurunan kondisi perusahaan sebelum mengalami kebangkrutan (Platt dan Platt, 2002). Suatu perusahaan dapat dikategorikan sedang mengalami financial distress atau kesulitan keuangan apabila perusahaan tersebut menunjukkan angka negatif pada laba operasi, laba bersih dan nilai buku ekuitas serta perusahaan tersebut melakukan merger (Hsin,2008). Fenomena lain dari financial distress adalah perusahaan cenderung mengalami kesulitan likuiditas yang ditunjukkan dengan kemampuan perusahaan yang semakin menurun dalam memenuhi kewajibannya kepada kreditur (Hanifah 2013).

Menurut Yu, C (2011), ada beberapa faktor penyebab financial distress yaitu Kesulitan arus kas, hal ini terjadi ketika penerimaan pendapatan perusahaan dari hasil kegiatan operasi tidak cukup untuk menutupi beban-beban usaha yang timbul atas aktivitas operasi perusahaan. Selain itu kesulitan arus kas juga bisa disebabkan karena adanya kesalahan manajemen ketika mengelola aliran kas perusahaan dalam melakukan pembayaran aktivitas perusahaan yang dapat memperburuk kondisi keuangan perusahaan. Demikian pula dengan besarnya jumlah utang dimana kebijakan pengambilan utang perusahaan untuk menutupi biaya yang timbul akibat operasi perusahaan akan menimbulkan kewajiban bagi perusahaan untuk mengembalikan utang dimasa mendatang. Ketika tagihan jatuh tempo, sedangkan perusahaan tidak mempunyai cukup dana untuk melunasi tagihantagihan tersebut, maka kemungkinan yang dilakukan kreditur adalah melakukan penyitaan harta perusahaan untuk menutupi kekurangan pembayaran tagihan tersebut. Sedangkan factor lain yang dapat menyebabkan financial distress adalah kerugian dalam kegiatan operasional perusahaan selama beberapa tahun. Dalam hal ini merupakan kerugian operasional perusahaan yang dapat menimbulkan arus kas negatif dalam perusahaan (Asquit,1991). Hal ini dapat terjadi karena beban operasional lebih besar dari pendapatan yang diterima perusahaan. Meskipun suatu perusahaan dapat mengatasi tiga masalah di atas, belum tentu perusahaan tersebut dapat terhindar dari financial distress, itu karena masih terdapat faktor eksternal perusahaan yang dapat menyebabkan financial distress. Menurut Kennedy (1991), faktor eksternal perusahaan lebih bersifat makro, di mana cakupannya lebih luas. Faktor eksternal dapat berupa kebijakan pemerintah yang dapat menambah beban usaha yang ditanggung perusahaan, misalnya tarif pajak yang meningkat dapat menambah beban perusahaan. Selain itu, masih ada kebijakan suku bunga pinjaman yang meningkat, dimana bisa menyebabkan peningkatan beban bunga yang ditanggung perusahaan.

Penelitian ini financial distress diproksikan menggunakan rasio keuangan untuk memberikan gambaran mengenai baik buruknya kondisi suatu perusahaan yaitu dengan rasio leverage, 
operating capacity dan profitabilitas. Dalam hal ini Leverage mengukur tingkat solvabilitas suatu perusahaan. Rasio ini menunjukkan kemampuan perusahaan untuk memenuhi segala kewajiban finansialnya seandainya perusahaan tersebut akan dilikuidasi. Apabila suatu perusahaan pembiayaannya lebih banyak menggunakan utang, hal ini beresiko akan terjadi kesulitan pembayaran di masa yang akan datang akibat utang lebih besar dari aset yang dimiliki (Ahmad,2012). Jika keadaan ini tidak dapat diatasi dengan sebaik mungkin, maka potensi terjadinya financial distress pun semakin besar. Leverage sering diartikan sebagai pendongkrak kinerja perusahaan dan identik dengan utang. Leverage menunjukkan kemampuan perusahaan untuk memenuhi kewajiban yang dimiliki oleh perusahaan tersebut. Rasio leverage yang biasa digunakan adalah rasio utang yaitu total utang dibagi dengan total aktiva (Fatma, 2017). Sedangakan Rasio Aktivitas atau yang sering disebut sebagai operating capacity dimana rasio ini digunakan untuk mengukur kemampuan perusahaan dalam menggunakan aset-asetnya secara efektif untuk menghasilkan penjualan. Rasio ini dinilai dari total asset turnover dengan membandingkan total penjualan dengan jumlah asset yang dimiliki suatu perusahaan (Atika, 2013). Demikian dengan Profitabilitas dihitung menggunakan return on equity. Rasio ini mengukur kemampuan perusahaan dalam menghasilkan laba semaksimal mungkin dengan menggunakan harta dan modal yang dimilikinya. Semakin tinggi profitabilitas maka semakin baik perputaran dana yang ada diperusahaan untuk menghasilkan laba (Marfungatun, 2017).

Corporate financial distress ditunjukkan sebagai proses tiga dimensi yang terdiri time frame, financial distress, dan process stages. Financial distress cycle dalam perusahaan mencakup periode awal penurunan kinerja hingga ke titik terendah kemudian tahap pemulihan apabila perusahaan bisa memperbaiki kinerjanya (Alman, E. 1968). Ketika perusahaan mengalami kesulitan keuangan, maka perusahaan tersebut tidak berada diposisi yang sama melainkan terus bertransisi ke tahapantahapan selanjutnya. Apabila kinerja semakin buruk, maka kemungkinan besar perusahaan akan menghadapi kebangkrutan. Namun, jika kinerja perusahaan membaik maka perusahaan memiliki kesempatan untuk mengatasi kesulitan keuangan (Purnomo, 2010)

\section{Metode Penelitian}

Subjek pada penelitian ini adalah perusahaan industri barang konsumsi yang terdaftar di Bursa Efek Indonesia (BEI) selama periode 2014-2017. Subjek tersebut dipilih karena industri barang dan konsumsi meruapakan sektor yang memproduksi barang konsumsi untuk kebutuhan sehari-hari, mengingat Indonesia adalah negara yang berkembang dengan populasi lebih dari 200 juta orang maka dipastikan sektor ini cukup aktif dipasar. Objek penelitian ini adalah Operating Capacity, Leverage dan Profitabilitas sebagai variabel independen dan Financial Distress sebagai variabel dependen. Jenis penelitian yang digunakan pada penelitian ini adalah data sekunder. Data sekunder adalah data yang diperoleh dalam bentuk yang telah jadi, telah diolah dan telah dipublikasikan. Serta penelitian ini bersifat kuantitatif dimana peneliti melakukan observasi serta melakukan pengukuran yang dimana dapat dinyatakan dengan angka - angka. Penelitian ini juga bersifat kasualitas yang artinya peneliti ingin mencari tahu hubungan sebab akiibat yang timbul antara variable independen dan variable dependen selaku variable yang dipengaruhi.

\section{Populasi dan Sampel Penelitian}

Populasi yang digunakan dalam penelitian ini adalah perusahaan industri barang konsumsi yang merupakan emiten di Bursa Efek Indonesia (BEI) selama 
periode 2014 - 2017. Dasar penentuan sampel ini adalah sampel yang memiliki kelengkapan data yang dibutuhkan. Metode pengumpulan sampel digunakan adalah purposive sampling yang merupakan metode pengumpulan sampel berdasarkan tujuan penelitian (Sugiono, 2015). Kriteria yang digunakan untuk memilih sampel adalah sebagai berikut :

1. Perusahaan industri barang dan konsumsi yang terdaftar di Bursa Efek Indonesia secara berturut turut selama tahun 2015 sampai 2017. Alasan peneliti memilih perusahaan tersebut dikarenakan perusahaan industri barang konsumsi merupakan sektor yang memproduksi barang konsumsi untuk kebutuhan sehari-hari masyarakat sehingga tingkat produktifitasnya tinggu, mengingat Indonesia adalah negara berkembang dengan popuplasi jiwa lebih dari 200 juta penduduk maka dipastikan sektor ini cukup aktif.

2. Perusahan yang telah menerbitkan laporan keuangan tahunan yang telah diaudit selama tahun 2014 sampai 2017.

3. Perusahaan yang menggunakan mata uang rupiah.

4. Perusahaan yang memiliki data keuangan yang lengkap terkait dengan penelitian.

\section{Metode Analisis}

Metode analisi yang digunakan dalam penelitian ini adalah menggunakan teknik analisis kuantitatif. Analisis kuantitatif dilakukan dengan cara menganalisis suatu permasalahan yang diwujudkan dalam bentuk angka. Dalam penelitian ini menggunakan pengujian hipotesis analisis regresi logistic (logistic regression) dengan bantuan software SPSS V.25. Alasan menggunakan regresi logistic karena untuk mencari keterkaitan antara variabel dalam penelitian ini, sebab data yang digunakan dalam penelitian ini bersifat non metric (dummy) pada variabel dependennya yaitu financial distress, sedangkan variabel independen (operating capacity, leverage dan profitabilitas) merupakan campuran antara variabel kontinyu (data metrik) dan kategorikal (data non metrik). Analisis regresi logistic tidak memerlukan asumsi normalitas data dan tidak perlu membuktikan asumsi klasik seperti multikolonieritas, autokorelasi dan heterokidastisitas (Ghozali, 2013). Tujuan dari model regresi dengan respon kualitatif pada variabel dependen adalah untuk menentukan probabilitas individu dalam keputusan yang bersifat kualitatif.

Model regresi logistik yang Terbentuk dilakukan untuk menguji seberapa jauh semua variabel independen yang dimasukkan dalam model mempunyai pengaruh terhadap kemungkinan terjadinya financial distress. Model yang digunakan dalam penelitian ini adalah sebagai berikut :

$F D I=\beta 0+\beta 1 X 1+\beta 2 X 2+\beta 3 X 3+\varepsilon$

\section{Dimana :}

FDI = financial distress ( 0 jika mengalami financial distress, 1 jika tidak mengalami financial distress)

$\beta 0=$ Konstanta

$\mathrm{X} 1=$ Operating Capacity (menggunakan rumus total assets turnover)

$\mathrm{X} 2=$ Leverage (menggunakan rumus debt ratio)

X3 = Profitabilitas (menggunakan rumus return on equity)

$\varepsilon=$ error

\section{Hasil Dan Pembahasan}

\section{Penyajian Data}

Berdasarkan kriteria pemilihan sampel, dihasilkan 11 sampel laporan keuangan tahunan perusahaan industri barang dan konsumsi di Bursa Efek Indonesia tahun 2014-2017 atau selama 4 tahun pengamatan dan diperoleh total 44 data

\section{Stastistik Deskriptif}

Berdasarkan data diatas maka diketahui variable operating capacity memiliki proporsi nilai minimum sebesar 0.12 dan maksimum 4.9 dengan 
rata-rata 1.16 dan standar deviasi 0.68 . Sedangkan variable leverage memiliki proporsi nilai minimum sebesar 0.17 dan maksimum 0.65 dengan rata-rata 0.42 dan stadar deviasi 0.13 .
Demikian pula dengan variabel profitabilitas memiliki proporsi nilai minimum sebesar 0.13 dan maksimum 0.24 dengan rata-rata 0.07 dan standar deviasi 0.08 .

\section{Tabel 1 Descriptive Statistics}

\begin{tabular}{llrrrr} 
& $\mathrm{N}$ & Minimum & \multicolumn{1}{c}{ Maximum } & \multicolumn{1}{l}{ Mean } & \multicolumn{1}{c}{ Std. Deviation } \\
\hline OP_CAP & 44 &, 1212 & 4,9077 & 1,163737 &, 6783440 \\
LEV & 44 &, 1769 &, 6559 &, 425628 &, 1316664 \\
PROFIT & 44 &,- 1392 &, 2407 &, 079764 &, 0866330 \\
Valid N (listwise) & 44 & & & &
\end{tabular}

Berdasarkan data table 1 diatas maka diketahui variable operating capacity memiliki proporsi nilai minimum sebesar 0.12 dan maksimum 4.9 dengan rata-rata 1.16 dan standar deviasi 0.68 . Sedangkan variable leverage memiliki proporsi nilai minimum sebesar 0.17 dan maksimum
0.65 dengan rata-rata 0.42 dan stadar deviasi 0.13. Demikian pula dengan variabel profitabilitas memiliki proporsi nilai minimum sebesar 0.13 dan maksimum 0.24 dengan rata-rata 0.07 dan standar deviasi 0.08 .

\section{Koefisien Determinasi}

Tabel. 2 Koefisien Determinasi

\begin{tabular}{|c|c|c|c|}
\hline Step & $\begin{array}{c}-2 \text { Log } \\
\text { likelihood }\end{array}$ & $\begin{array}{c}\text { Cox \& Snell R } \\
\text { Square }\end{array}$ & Nagelkerke R Square \\
\hline 1 & $16,064^{\mathrm{a}}$ &, 290 &, 572 \\
\hline
\end{tabular}

Hasil uji koefisien determinasi dapat dilihat dari besarnya nilai Nagelkerke R Square. Berdasarkan table diatas diperoleh nilai Nagelkerke $R$ Square sebesar 0.572 yang artinya sebesar $57.2 \%$ variablitias variable dependen dijelaskan oleh variable independen, sedangkan sisanya $42.8 \%$ dijelaskan oleh variable lain diluar penelitian.

\section{Classification Tabel}

Tabel 3 Classification Table ${ }^{a}$

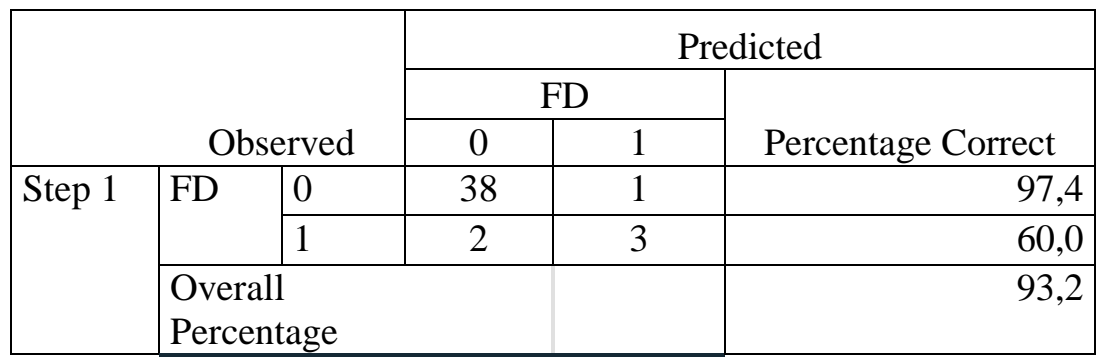


Angka pada tabel diatas digunakan untuk menghitung nilai prediksi dari variable dependen, yang dimana dalam penelitian ini financial distress dan non financial distress. Dari hasil pengujian diatas menunjukan bahwa kekuatan model regresi dalam memprediksi indikasi perusahaan yang akan mengalami financial distress adalah $60 \%$, dari total sampel 5 dan yang salah diprediksi mengalami financial distress sebanyak 2 sampel. Sedangkan kekuatan model regresi dalam memprediksi indikasi perusahaan yang tidak mengalami financial distress adalah $97.4 \%$, dari total 39 sampel yang diprediksi tidak mengalami financial distress sebanyak 38 sampel, dan yang salah diprediksi sebesar 1 sampel. Adapun nilai overall percentage pada tabel diatas sebesar 93.2\% yang berarti ketetapan model penelitian ini adalah sebesar 93.2\% .

\section{Uji Regresi Logistik}

Tabel 4

Pengujian Hipotesis

\begin{tabular}{llrrrrrr}
\hline & & \multicolumn{1}{c}{ B } & \multicolumn{1}{c}{ S.E. } & Wald & Df & \multicolumn{1}{c}{ Sig. } & \multicolumn{1}{c}{$\operatorname{Exp}(\mathrm{B})$} \\
\hline Step 1 $^{\text {a }}$ & OP_CAP & $-1,697$ & 2,052 &, 684 & 1 &, 408 &, 183 \\
& LEV & 3,699 & 5,818 &, 404 & 1 &, 525 & 40,394 \\
& PROFIT & $-24,051$ & 11,295 & 4,534 & 1 &, 033 &, 000 \\
& Constant & $-1,768$ & 3,485 &, 257 & 1 &, 612 &, 171
\end{tabular}

Penelitian ini menggunakan variable dependen yang memiliki dua kategori yaitu financial distress dan menggunakan model regresi logistik. Regresi logstik dalam penelitian ini digunakan untuk menguji pengaruh operating capacity, leverage, dan profitabilitas terhadap financial distress. Nilai probabilitas yang digunakan untuk menguji signifikansi koefisien dari setiap variable bebas adalah sebesar 5\% (0.05). apabila nilai signifikansi lebih kecil dari 0.05 makan koefisiensi regresi adalah signifikan dan juga sebaliknya, jika signifikansi lebih besar dari 0.05 maka tidak signifikan.

\section{Interprestasi Data}

Pengaruh Operating Capacity

(X1) Terhadap Financial Distress (Y)

Operating capacity menggambarkan efisiensi aktivitas operasional perusahaan. Operating capacity diukur dengan menggunakan rasio perputaran total aktiva.
Total Asset Turnover $=$ Sales $:$ Total Aset ...........................(1)

Perputaran total aktiva yang tinggi menunjukkan efektivitas perusahaan dalam penggunaan aktiva untuk menghasilkan penjualan. Hal ini merupakan sinyal positif karena dengan adanya efektivitas penggunaan aktiva untuk menghasilkan penjualan diharapkan dapat memberikan keuntungan yang semakin besar bagi perusahaan dan menunjukkan bahwa kinerja keuangan yang dicapai oleh perusahaan semakin baik sehingga terjadinya kemungkinan terjadinya financial distress semakin kecil. Menurut Lisiantara dan Lilik (2018) operating capacity berpengaruh terhadap financial distress,

Beradasarkan hasil olah data untuk hipotesis pertama (Hal) dalam penelitian ini menyatakan bahwa operating capacity berpengaruh terhadap financial distress. Berdasarkan tabel 4 menunjukan bahwa variabel operating capacity memiliki nilai beta korelasi sebesar -1.697 dengan signifikansi 
sebesar 0.408. Nilai signifikansi yang berada diatas 0.05 menunjukan tidak adanya pengaruh yang signifikan. Sehingga Ha1 ditolak dan dapat disimpulkan bahwa operating capacity tidak berpengaruh terhadap financial distress. Penelitian ini bertolak belakang dengan penelitian Lisiantara dan Lilik (2018) dimana operating capacity berpengaruh terhadap financial distress, namun selaras dengan penelitian Dewi, Khairunnisa dan Dewa (2017). Hal ini dikarenakan nilai operating capacity perusahaan yang tidak mengalami kondisi financial distress seharusnya berada diatas rata-rata perusahaan yang megalami kondisi financial distress. Hal ini mungkin disebabkan beberapa perusahaan yang tidak mengalami kondisi financial distress mengalami total asset turnover yang lambat. Operating capacity pada perusahaan yang tidak mengalami financial distress seharusnya dari tahun ke tahun penjualannya mengalami peningkatan dan total aset menurun. Dimana penjualan yang meningkat dan total aset yang menurun mengindikasikan adanya laba yang meningkat sehingga total asset turnover juga meningkat.

\section{Pengaruh Leverage (X2) Terhadap Financial Distress (Y)}

Leverage menunjukkan besarnya dana yang disediakan oleh kreditur. Rasio leverage diproksikan dengan rasio utang (debt ratio) yaitu jumlah kewajiban dibagi dengan jumlah aset. Dengan kata lain, seberapa besar aktiva perusahaan dibiayai oleh utang atau seberapa besar utang perusahaan berpengaruh terhadap pengelolaan aktiva. Rasio ini diukur dengan menggunakan

\section{Debt Ratio $=\underline{\text { Total Liabilities }}$}

Total Assets ....

Apabila perusahaan memiliki tingkat leverage yang tinggi maka kreditur akan meminta "rate of interest" yang tinggi. Semakin tinggi pinjaman perusahaan maka semakin tinggi "rate of interest" yang diminta oleh kreditur. Hal ini akan memberikan sinyal yang negatif bagi kreditur, sebab semakin besar hutang maka semakin tinggi kemungkinan perusahaan tidak mampu melunasi hutang-hutangnya ketika jatuh tempo, sehingga dapat menjadi indikasi bahwa nantinya perusahaan akan mengalami financial distress. Menurut Triwahyuningtias (2012) leverage dapat mempengaruhi financial distress

Hipotesis kedua (Ha2) menyatakan bahwa leverage berpengaruh terhadap financial distress. Berdasarkan tabel 4 menunjukan bahwa variabel leverage memiliki nilai beta korelasi sebesar 3.699 dengan signifikansi sebesar 0.525 . Nilai signifikansi yang berada diatas 0.05 menunjukan tidak adanya pengaruh yang signifikan. Sehingga Ha2 ditolak dan dapat disimpulkan bahwa leverage tidak berpengaruh terhadap financial distress. Penelitian ini bertolak belakang dengan penelitian Susilawati, Diamonalisa dan Edi (2016) dimana leverage berpengaruh terhadap financial distress, namun penelitian ini selaras dengan penelitian Widhiari dan Ni.K (2015). Tidak berpengaruhnya rasio leverage ini dimungkinkan karena total liabilitas perusahaan industri barang dan konsumsi besar namun total aset yang dimiliki perusahaan juga besar, maka perusahaan mampu membayar liabilitas dengan aset yang dimiliki perusahaan.

\section{Pengaruh Profitabilitas (X3) Terhadap Financial Distress (Y)}

Hipotesis ketiga (Ha3) menyatakan bahwa profitabilitas yang diproxikan dengan return on equity (ROE) yang diperoleh dari Earning After Tax dibagi dengan total equity berpengaruh terhadap financial distress. Berdasarkan tabel 4 menunjukan bahwa variabel profitabilitas memiliki nilai beta korelasi sebesar -24.051 dengan signifikasi sebesar 0.33 Nilai signifikansi yang berada diatas 0.05 menunjukan tidak adanya pengaruh yang signifikan. 
Sehingga Ha3 diterima dan dapat disimpulkan variabel profitabilitas memiliki pengaruh terhadap financial distress. Penelitian ini bertolak belakang dengan Murni (2018) dimana profitabilitas tidak berpengaruh terhadap financial distress, namun selaras dengan penelitian Widati dan Bayu (2015). Semakin tinggi nya return atau penghasilan yang diperoleh semakin baik pula keadaan keuangan perusahaan, karena tinggi nya tingkat laba yang dihasilkan menandakan bahwa perusahaan tersebut tidak mengalami financial distress atau bisa dibilang bahwa keadaan perusahaan tersebut sehat.

\section{Simpulan}

Penelitian ini bertujuan untuk mengetahui apakah operating capacity, leverage dan profitabilitas yang di proksi dengan return on equity berpengaruh terhadap financial distress. Berdasarkan uji regresi logistik yang dilakukan, variabel operating capacity tidak berpengaruh signifikan terhadap kondisi financial distress, dikarenakan nilai operating capacity perusahaan non financial distress seharusnya berada diatas rata-rata perusahaan yang mengalami kondisi financial distress, sedangakan variabel leverage tidak berpengaruh signifikan terhadap kondisi financial distress, dikarenakan perusahaan memiliki total aset dan total liabilitas yang sama besar, sehingga perusahaan mampu membayar liabilitas dengan aset yang dimiliki perusahaan tersebut dan variabel profitabilitas yang diproksi menggunakan return on equity tidak berpengaruh signifikan terhadap financial distress, dikarenakan tinggi nya tingkat laba yang didapat sehingga perusahaan tidak mengalami kesusahan dalam kondisi keuangan.

Berdasarkan kesimpulan dan keterbatasan penelitian maka saran yang dapat diberikan oleh peneliti untuk penelitian selanjutnya dapat memperluas perusahaan yang akan diteliti dimana tidak hanya perusahaan industri barang dan konsumsi tetapi seluruh perusahaan manufaktur atau seluruh perusahaan yang terdaftar di Bursa Efek Indonesia, selanjutnya dapat menambahkan variabel-variabel lain agar hasil peneliitain ini dapat dikembangkan lebih luas sehingga dapat membantu para investor sebagai dasar acuan dalam mengambil keputusan yang tepat untuk berinvestasi.

Adapun keterbatasan dalam penelitian ini antara lain hanya menggunakan 3 indikator keuangan, dan 11 sampel penelitian selama satu periode sehingga sampel yang digunakan untuk menguji tidak seluas dari peneliti terdahulu demikian pula periode yang digunakan hanya menggunakan data laporan keuangan tahunan 2014 sampai 2017 untuk memprediksi. Kemampuan prediksi dipercaya akan semakin baik apabila jangka waktu nya lebih panjang.

\section{Daftar Pustaka}

Alifiah, M., N. Salamudin, dan I. Ahmad. 2012. Prediction of Financial Distress Companies in the Consumer Products Sector in Malaysia. "jurnal UTM 2013, h. 112.

Altman, E. 1968. Financial Ratio, Discriminant Analysis, and the Prediction of Corporate Bankruptcy. "The Journal of Finance, September, Vol. 23, h. 589-609.

Al-Khatib, H dan A. Al-Horani. 2012. Predicting Financial Distress of Public Companies Listed in Stock Exchange." European Scientific Journal, July edition vol. 8, No.15, h. 208-215.

Ahmad, G. 2012. Analysis of Financial Distress in Indonesian Stock Exchange. "Rev. Integr.

Bus. Econ. Res, Vol 2(2), h. 6-36

Asquith, P., Genter, R., \& Scharfstein, D. (1991). Anatomy of Financial Distress: An Examination of Junk Bonds Issuers(No. 3942). 
Atika, Darminto, \& Handayani, S.R. (2013). Pengaruh Beberapa Rasio Keuangan Terhadap Prdiksi Kondisi Financial Distress, Jurnal Administrasi Bisnis, 1 (2). 1 - 11

Dewi, R. J., Khairunnisa, \& Mahardika, D. P. (2017). Analisis Pengaruh Likuiditas, Leverage dan Operating Capacity Terhadap Financial Distress. bandung: Universitas Telkom ISSN : 2355 9357.

Fatma \& Viviwati, V. (2017). Pengaruh Likuiditas, Leverage, Aktivitas Dan Provitabilita Dalam Memprediksi Financial Distress. Jurnal Ilmu Dan Riset Akuntansi, 6 Retrieved from http://Journal.stiesia.ac.id/sju/ind ex.php/aa.

Gholizadeh,M. H. et al. 2011. "CorporateFinancial DistressPredictionUsing Artificial Neural

Networksand Using Micro-Level FinancialIndicators". Interdisciplinary Journal of ContemporaryResearchin Business.Vol 3, No 5 . (September):pp. 595-605

Ghozali, (2013). Aplikasi Analisis Multivariate dengan Program SPSS. Edisi Ketujuh. Semarang: Badan Penelitian Universitas Diponegoro.

Hanifah, O. 2013. Pengaruh Struktur Corporate Governance dan Financial Indicators Terhadap Kondisi Financial Distress. "jurnal maksi undip, h. 25-53

Hsin, H. C. 2008. "The TimescaleEffects ofCorporateGovemanceMeasure on Predicting Financial Distress". Review of Pacific Basin Financial Marketsand Policies.Vol. 11,No. 1.pp. 35-46

Imanzadeh, P.J.M. \& M. Sepehri. (2011). A Study of The Appliction of Springate And Zmijewski Bangkruftcy Prediction Models in Firms Acepted in Tehran Stock Exchange. Astralian Journal Of Apllied Sciences. Vol 25 (3): $321-335$

Kennedy, D. B., dan W. H. Shaw. 1991. "Evaluating Financial Distress Resolution Using Prior Audit Opinions" ContemporaryAccounting ResearchVol.. 8, No. 1. PP.97'114.

Kasmir. (2012). Analisis Laporan Keuangan. Jakarta: PT. Raja Grafindo Persada.

Kordestani,G. et al.201 1. "Ability of Combinationsof CashFlow Components to Predict Financial Distress". Business:Theoryand Practice. Vol. 12, No. 277-285

Lisiantara, G. A., \& Febriana, L. (2018). Likuiditas, Leverage, Operating Capacity, Profitabilitas, Sales Growth Sebagai Preditor Financial Distress.Fakultas Ekonomika dan Bisnis, Universitas Stikubank Semarang.ISBN: 978-979-364999-3

Marfungatun, F. (2017) Pengaruh Rasio Profitabilitas, Likuiditas, Dan Leverage, Terhadap

kondisi Financial Distress Perusahaan Manufaktur Yang Terdaftar Di Bursa Efek Indonesia. Https://Repositor. Upy. Ac.Id/Id/Eprint/1281.

Masdupi, E., Tasman, A., \& Davista, A. (2018). The Influence Of LIquidity, Leverage and Profitability on Financial Distress of Listed Manufacturing Companies In Indonesia. Advances in Economics, Business and Management Reserach, Volume 57.

Murni, M. (2018). Analisis Faktor-Faktor yang Mempengaruhi Tingkat Financial Distress pada Perusahaan Manufaktur yang Terdaftar di BEI Tahun 2010- 
2015. Jurnal Akuntansi dan Bisnis, Vol 4. ISSN : 2243-3071.

Nella, R. 2011. Analisis Rasio Keuangan dalam Memprediksi Financial Distress Perusahaan Wholesale and Retail Trade yang Terdaftar di Bursa Efek Indonesia. "journal of accounting, h.1-14

Plat, H., \& Plat, M. B. (2002). Predicting Financial Distress, Vol.56, p1215.Pranowo, K. et al. 2010. "Determinant of Corporate Financial Distress in an Emerging Pustylnick, 1. 2012. "Restructuring The Financial Characteristiesof Projects in FinancialDistress".Global Journal of Business Research Vol.. 6, No. 2. pp.125-134.

Rudianto. (2013). Akuntansi Manajemen Informasi untuk Pengambilan Keputusan Strategis. Jakarta: Erlangga.

Sugiyono. (2015). Metode Penelitian Kombinasi: Mix Methods. Bandung: Alfabeta.

Susilawati, D., Sofianty, D., \& Sukarmonto', E. (2016). Pengaruh Profitabilitas, Ukuran Perusahaan dan Leverage Terhadap Financial Distress Pada Perusahaan yang Terdaftar di Bursa Efek Indonesia (BEI). bandung: Fakultas Ekonomi dan BIsnis, Universitas Islam Bandung ISSN : 2460-6561.

Triwahyuningtias, M. 2012. Analisis Pengaruh Struktur Kepemilikan,
Ukuran Dewan, Komisaris Independen, Likuiditas dan Leverage Terhadap Terjadinya Kondisi Financial Distress. "jurnal maksi undip, h 34-37.

Widharia, N. L., \& Merkusiwati, N. K. (2015). Pengaruh Rasio Likuiditas, Leverage, Operating Capacity, dan Sales Growth Terhadap Financial Distress.EJurnal Akuntansi Universitas Udayana ISSN: 2302-8556

Widawati, L. W., \& Pratama, B. A., (2015). Pengaruh Current Ratio, Debt To Eqtity, dan Return On Equity untuk Memprediksi Kondisi Financial Distress. Semintar Nasional Multi Disiplin Ilmu \& Call For Paper UNISBANK ISBN : 978-9793649-81-8

Yadiati, W. (2017). The Influence of Prafitability on Financial Distress: A Research on Agricultural Companies Listed in Indonesia Stock Exchange. International Journal of Scientific \& Technology Research Vol 6, Issue 11ISSN 2277-8616.

$\mathrm{Yu}, \quad$ C. et al.2011. "Predicting FinancialDistressof

ChineseListed Companies Using Rough Set Theory and Support Vector Machine". AsiaPacific Journal of Operational Research Vol.28 No. 1. Pp 95 109 